\title{
HASIL PEMERIKSAAN DARAH RUTIN TERHADAP MANIFESTASI PERDARAHAN PADA ANAK DENGAN DIAGNOSIS INFEKSI DENGUE DI RS DR. A. DADI TJOKRODIPO
}

\section{ROUTINE BLOOD TEST RESULT TO BLEEDING MANIFESTATION ON CHILDREN DIAGNOSED WITH DENGUE INFECTION AT DR. A. DADI. TJOKRODIPO HOSPITAL}

\author{
Bella Pratiwi Anzani \\ Fakultas Kedokteran, Universitas Lampung, Lampung, Indonesia \\ (email penulis korespodensi: bellapratiwi789@gmail.com )
}

Info Artikel: Diterima: 30 April $2019 \quad$ Revisi: 15 Mei $2019 \quad$ Diterima: 31 Mei 2019

\begin{abstract}
ABSTRAK
Latar Belakang: Manifestasi klinis pada infeksi dengue yang timbul pada dewasa dan anak berbeda. Manifestasi yang sering muncul pada dewasa berupa myalgia, nyeri retro orbital, mual dan atralgia, sedangkan pada anak berupa myalgia, sakit kepala dan manifestasi perdarahan. Tujuan dari penelitian ini adalah mengetahui hubungan hasil pemeriksaan darah rutin terhadap manifestasi perdarahan pada anak dengan diagnosis infeksi dengue.

Metode: Penelitian ini menggunakan analitik observasional dengan pendekatan cross sectional. Penelitian dilakukan di IGD RS Dr. A. Dadi Tjokrodipo pada bulan Oktober-Desember 2017. Jumlah sampel penelitian 24 orang dengan menggunakan total sampling. Pemeriksaan darah rutin dilakukan menggunakan hematology analyzer. Manifestasi perdarahan didapatkan dari anamnesis dan pemeriksaan fisik pasien.

Hasil: Hasil yang didapatkan menggunakan uji fisher's exact mengenai hubungan trombosit terhadap manifestasi perdarahan didapatkan $p$ value 0,015 . Hubungan leukosit terhadap manifestasi perdarahan didapatkan $p$ value 0,423 . Hubungan hematokrit terhadap manifestasi perdarahan didapatkan $p$ value 1,00. Hubungan hemoglobin terhadap manifestasi perdarahan didapatkan $p$ value 1,00.

Kesimpulan: Terdapat hubungan yang bermakna antara jumlah trombosit terhadap manifestasi perdarahan, namun tidak terdapat hubungan bermakna antara leukosit, hematokrit dan hemoglobin terhadap manifestasi perdarahan pada pasien anak dengan infeksi dengue.
\end{abstract}

Kata kunci: DBD, pemeriksaan darah rutin, perdarahan

\begin{abstract}
Background: Clinical manifestations of dengue infections which appears in adults and children are different. Manifestations that often appear in adults such as myalgia, retro orbital pain, nausea and atralgia, whereas in children such as myalgia, headache and bleeding manifestations. The purpose of this study was to investigate the relationship of routine blood tests to bleeding manifestation in children with dengue infection diagnosis.

Method: This study uses observational analytics with cross sectional approach. This study was conducted at IGD RS Dr. A. Dadi Tjokrodipo in October-December 2017. Total sampling that used for this research is 24 persons and done with total sampling method. Routine blood tests are performed using a hematology analyzer. Bleeding manifestations are obtained from anamnesis and physical examination of the patient.

Result: The result obtained using fisher's exact test about the relationship of thrombocyte to bleeding manifestation obtained $p$ value 0,015. The relationship of leukocytes to bleeding manifestation was obtained $p$ value 0.423. The hematocrit relationship to bleeding manifestation was obtained $p$ value 1.00. The relationship of hemoglobin to bleeding manifestation was obtained p value 1.00.

Conclusion: There is a significant relationship between platelet to bleeding manifestation, but there is no significant relationship between leukocytes, hematocrit and hemoglobin against bleeding manifestation in patients with dengue infection.
\end{abstract}

Keywords: DHF, routine blood test, bleeding 


\section{PENDAHULUAN}

Infeksi dengue merupakan infeksi yang ditransmisikan oleh nyamuk dan merupakan penyakit yang penyebarannya sangat cepat di dunia. Virus dengue termasuk dalam genus flavivirus dan famili flaviviridae yang memiliki 4 serotype yaitu DEN-1, DEN-2, DEN-3, dan DEN-4. ${ }^{1}$ Indonesia merupakan negara dengan penyakit infeksi dengue tertinggi di Asia Tenggara sejak tahun 1968 hingga 2009. Penyakit ini masih menjadi masalah kesehatan masyarakat di Indonesia, khususnya pada provinsi Lampung yang penyebarannya semakin luas dan cenderung meningkat sehingga berpotensi menimbulkan Kejadian Luar Biasa (KLB), ${ }^{2,3}$

Faktor-faktor yang mempengaruhi terjadinya infeksi dengue terbagi menjadi tiga faktor yaitu faktor penyebab (agent), pejamu (host) dan lingkungan (environment). Faktor penyebab (agent) adalah virus dengue yang memioliki 4 serotype yaitu DEN-1, DEN-2, DEN-3, DEN-4. Faktor pejamu (host) yaitu manusia, faktor ini dapat dikelompokkan berdasarkan usia, jenis kelamin, imunitas, status gizi dan interaksi antar pejamu dengan penyebab secara biologis. Contohnya pada Dengue Shock Syndroma (DSS), frekuensi yang lebih tinggi terkena DSS adalah kelompok yang memiliki keterbatasan sistem imun diantaranya yaitu anak-anak yang telah mengalami infeksi dengue sebelumnya, dan bayi dengan peyusutan kadar antibodi dengue maternal. Faktor lingkungan (environment) yang mempengaruhi terjadinya infeksi dengue adalah suhu, kelembaban, iklim dan curah hujan. ${ }^{4,5}$

Dalam menegakkan diagnosis penyakit infeksi dengue didasarkan pada gejala klinis dan pemeriksaan laboratorium. Gejala klinis infeksi dengue berupa manifestasi demam tinggi

\section{BAHAN DAN METODE}

Penelitian ini menggunakan desain penelitian analitik observasional dengan pendekatan cross sectional. Penelitian dilakukan di IGD RS Dr. A. Dadi Tjokrodipo pada bulan Oktober-Desember 2017. Jumlah sampel penelitian ini sebanyak 24 orang dengan menggunakan total sampling. Pemeriksaan darah rutin dilakukan menggunakan hematology mendadak selama 2-7 hari, perdarahan, hepatomegali dan syok, sedangkan yang termasuk dalam pemeriksaan laboratorium infeksi dengue adalah trombositopenia dan hemokonsentrasi. Pemeriksaan laboratorium didapatkan dari pemeriksaan darah rutin yang meliputi pemeriksaan jumlah trombosit, kadar hemoglobin, nilai hematokrit, jumlah leukosit, eritrosit dan laju endap darah (LED). ${ }^{3}$

Manifestasi klinis yang timbul pada dewasa dan anak berbeda. Manifestasi yang sering muncul pada dewasa berupa myalgia, nyeri retro orbital, mual dan atralgia. Sedangkan manifestasi yang lebih sering muncul pada anak berupa myalgia, sakit kepala dan manifestasi perdarahan. Manifestasi perdarahan yang timbul pada infeksi dengue dapat disebabkan karena trombositopenia. Akan tetapi pada setiap pasien infeksi dengue dapat memiliki manifestasi klinis yang berbeda, pasien yang mengalami trombositopenia tidak selalu disertai dengan manifestasi perdarahan. ${ }^{6,8}$ Berdasarkan hasil penelitian pada pasien infeksi dengue yang memiliki jumlah trombosit kurang dari $50.000 / \mathrm{mm}^{3}$ memiliki risiko tinggi untuk terjadinya perdarahan dan pada anak-anak dengan leukopenia memiliki risiko mengalami dengue shock syndrome (DSS) 2,9 kali lebih tinggi mengalami syok dibandingkan penderita infeksi dengue pada anak tanpa leukopenia, namun manifestasi perdarahan pada infeksi dengue tidak berhubungan dengan jumlah trombosit. ${ }^{9}, 11$

Berdasarkan latar belakang di atas, pada penelitian ini peneliti bermaksud untuk mengetahui hubungan hasil pemeriksaan darah rutin terhadap manifestasi perdarahan pada anak yang terinfeksi dengue.

analyzer. Manifestasi perdarahan didapatkan dari anamnesis dan pemeriksaan fisik pasien. Variabel penelitian terdiri dari variabel dependen dan variabel independen. Variabel dependen pada penelitian ini adalah pemeriksaan darah rutin yang meliputi jumlah trombosit, jumlah leukosit, nilai hematokrit dan kadar hemoglobin, sedangkan variabel 
independen yang dimaksud adalah manifestasi perdarahan yang dibagi menjadi perdarahan ringan, sedang dan berat. Kriteria perdarahan ringan jika terdapat rumple leed + atau ptekie, perdarahan sedang jika terdapat ruam, perdarahan gusi atau epistaksis. Perdarahan berat jika terdapat hematemesis atau melena. Kriteria inklusi dalam penelitian ini yaitu pasien dengan diagnosis infeksi dengue umur 1-15 tahun dan pasien bersedia menjadi responden.

\section{HASIL}

Tabel 1 menggambarkan karakteristik pasien anak yang mengalami infeksi dengue menurut jenis kelamin. Karakteristik responden berdasarkan jenis kelamin yang terbanyak
Sedangkan kriteria ekslusi dalam penelitian ini adalah sebagai berikut:

1. Pasien yang sedang mengonsumsi obatobat yang mensupresi sumsum tulang contohnya kloramfenikol;

2. Pasien yang memiliki riwayat penyakit kelainan darah, misalnya thalassemia, anemia, leukemia;

3. Pasien dengan penyakit koinsiden lain, misalnya demam tifoid, malaria.

Tabel 1. Distribusi Responden Menurut Jenis kelamin dan Umur (n=24)

\begin{tabular}{lcc}
\hline Variabel & Frekuensi & Persentase (\%) \\
\hline Jenis kelamin & 8 & 33,3 \\
1. Laki-laki & 16 & 66,7 \\
2. Perempuan & & \\
Umur & 12 & 50 \\
1. 1-5 tahun & 8 & 33,3 \\
2. 6-10 tahun & 4 & 16,7 \\
3. $11-15$ & & \\
\hline
\end{tabular}

Tabel 2 menggambarkan karakteristik pasien infeksi dengue menurut derajat keparahan penyakit yang terdiri dari DD, DBD grade I dan II, DSS. Dari data tersebut adalah perempuan sebanyak 16 orang $(66,7 \%)$ dan laki-laki sebanyak 8 orang $(33,3 \%)$ dan kelompok umur terbanyak yaitu $1-5$ tahun sebanyak 12 responden $(50 \%)$

didapatkan pasien anak yang mengalami DD

sebanyak 5 orang $(20,8 \%)$, DBD grade I sebanyak 12 orang (50\%), DBD grade II sebanyak 7 orang $(29,2 \%)$ dan tidak didapatkan pasien dengan DSS.

Tabel 2. Karakteristik Menurut Derajat Keparahan

\begin{tabular}{cccc}
\hline Derajat keparahan penyakit & Frekuensi & Persentase (\%) \\
\hline 1. & DD & 5 & 20,8 \\
2. & DBD grade I & 12 & 50 \\
3. & DBD grade II & 7 & 29,2 \\
4. & DSS & 0 & 0 \\
\hline \multicolumn{2}{c}{ Jumlah } & $\mathbf{2 4}$ & $\mathbf{1 0 0}$ \\
\hline
\end{tabular}

Tabel 3 menunjukkan gambaran jumlah trombosit pada pasien infeksi dengue Analisis univariat gambaran jumlah trombosit menunjukkan bahwa jumlah trombosit 18 pasien $(75 \%)$ yaitu kurang dari $100.000 / \mathrm{mm}^{3}$,
6 pasien (25\%) memiliki jumlah trombosit $100.000 / \mathrm{mm}^{3}$ sampai $150.000 / \mathrm{mm}^{3}$ dan tidak didapatkan pasien yang memiliki jumlah trombosit lebih dari $150.000 / \mathrm{mm}^{3}$. 
(JPP) Jurnal Kesehatan Poltekkes Palembang

Vol. 14, No. 1, Juni 2019, eISSN 2654-3427

Tabel 3.Gambaran Jumlah Trombosit, Leukosit, Hematokrit dan Kadar Hemoglobin pada Pasien Anak Dengan Diagnosis Infeksi Dengue $(\mathrm{n}=24)$

\begin{tabular}{|c|c|c|}
\hline Jumlah Trombosit $\left(/ \mathrm{mm}^{3}\right)$ & Frekuensi & Persentase (\%) \\
\hline 1. $<100.000$ & 18 & 75 \\
\hline 2. $100.000-150.000$ & 6 & 25 \\
\hline 3. $>150.000$ & 0 & 0 \\
\hline \multicolumn{3}{|l|}{ Jumlah leukosit $\left(/ \mathrm{mm}^{3}\right)$} \\
\hline 1. $<5000$ & 13 & 54,2 \\
\hline 2. $5000-10000$ & 11 & 45,8 \\
\hline 3. $>10000$ & 0 & 0 \\
\hline \multicolumn{3}{|l|}{ Nilai hematokit(\%) } \\
\hline 1. $>40$ & 10 & 41 \\
\hline 2. $35-40$ & 14 & 59 \\
\hline \multicolumn{3}{|l|}{ Kadar hemoglobin (g/dl) } \\
\hline 1. $<10$ & 1 & 4 \\
\hline 2. $10-16$ & 23 & 94 \\
\hline
\end{tabular}

Tabel 3 menjelaskan bahwa gambaran jumlah leukosit pada pasien anak dengan infeksi dengue disajikan dalam tabel 5. Jumlah leukosit dikelompokkan menjadi tiga kelompok. yaitu leukosit $<5000 \mathrm{~mm} 3$, 5000$10000 / \mathrm{mm}^{3}$ dan $>10000 \mathrm{~mm}$. Analisis univariat jumlah leukosit menunjukkan 13 pasien anak $(54,2 \%)$ memiliki jumlah leukosit kurang dari $5000 / \mathrm{mm}^{3}, 11$ pasien memiliki jumlah leukosit $5000-10000 / \mathrm{mm}^{3}$ dan tidak didapatkan pasien dengan jumlah leukosit lebih dari $10000 / \mathrm{mm}^{3}$. Analisis univariat nilai hematokrit pada tabel 6 menunjukkan bahwa terdapat 10 pasien $(41 \%)$ yang memiliki nilai hematokrit tinggi atau lebih dari $40 \%$ dan 14 pasien $(59 \%)$ yang memilki nilai hematokrit normal atau 35-40 \%. kadar hemoglobin normal yaitu sebanyak 23 pasien $(96 \%)$ atau $10-16 \mathrm{~g} / \mathrm{dl}$ dan hanya 1 pasien (4\%) yang memiliki kadar hemoglobin kurang dari 10 $\mathrm{g} / \mathrm{dl}$.

Tabel 4. Hubungan Antara Jumlah Trombosit Terhadap Manifestasi Perdarahan (n=24)

\begin{tabular}{|c|c|c|c|c|c|c|c|}
\hline \multirow[t]{3}{*}{ Variabel } & & \multicolumn{4}{|c|}{$\begin{array}{c}\text { Hasil Pemeriksaan Manifestasi } \\
\text { Perdarahan }\end{array}$} & \multirow[t]{3}{*}{ Jumlah } & \multirow[t]{3}{*}{$\begin{array}{c}p \\
\text { value }\end{array}$} \\
\hline & & \multicolumn{2}{|c|}{ Sedang } & \multicolumn{2}{|c|}{ Ringan } & & \\
\hline & & $\mathbf{n}$ & $\%$ & $\mathbf{n}$ & $\%$ & & \\
\hline Jumlah & $<5000$ & 7 & 53,8 & 6 & 46,2 & 13 & \\
\hline leukosit & $5000-10.000$ & 8 & 72,7 & 3 & 27,3 & 11 & 0,423 \\
\hline Jumlah & $<100.000$ & 14 & 77,8 & 4 & 22,2 & 18 & 0,015 \\
\hline trombosit & $100.000-150.000$ & 1 & 16,7 & 5 & 83,3 & 6 & \\
\hline Nilai & $>40$ & 6 & 60 & 4 & 40 & 10 & 1,00 \\
\hline hematokrit & $34-40$ & 9 & 64,3 & 5 & 35,7 & 14 & \\
\hline Kadar & $<10$ & 1 & 100 & 0 & 0 & 1 & 1,00 \\
\hline hemoglobin & $10-16$ & 44 & 60,9 & 9 & 39,1 & 23 & \\
\hline
\end{tabular}

Berdasarkan analisis bivariat antara hubungan jumlah trombosit dengan manifestasi perdarahan yang disajikan pada tabel 8 , diketahui bahwa pasien yang memiliki jumlah trombosit $<100.000$ sebanyak 18 orang, dari 18 orang tersebut, 4 orang memiliki manifestasi perdarahan ringan dan 14 orang yang memiliki perdarahan sedang. Berdasarkan uji statistik, didapatkan $p$ value sebesar 0,015 .
Pada analisis bivariat antara jumlah leukosit dengan manifestasi perdarahan yang disajikan dalam tabel 9, diketahui bahwa pasien yang memiliki jumlah leukosit kurang dari $5000 / \mathrm{mm}^{3}$, sebanyak 6 pasien mengalami perdarahan ringan dan 7 pasien memiliki manifestasi perdarahan sedang. Sedangkan pada pasien dengan jumlah leukosit 5000$10.000 / \mathrm{mm}^{3}$, sebanyak 3 pasien memiliki 
manifestasi perdarahan ringan, 8 pasien memiliki perdarahan sedang, didapatkan $p$ value 0,423 .

Berdasarkan analisis bivariat nilai hematokrit dengan manifestasi perdarahan yang disajikan pada tabel 10, diketahui bahwa pasien dengan nilai hematokrit meningkat atau lebih dari $40 \%$ yang memiliki manifestasi perdarahan ringan sebanyak 4 pasien dan 5 pasien memiliki perdarahan sedang. Sedangkan pada pasien dengan nilai hematokrit normal atau $34-40 \%$, yang memiliki perdarahan ringan sebanyak 5 orang dan 9 orang memiliki perdarahan sedang. Nilai

\section{PEMBAHASAN}

Berdasarkan penelitian yang telah dilakukan, didapatkan 24 sampel anak dengan diagnosis klinis infeksi dengue. Sampel yang didapatkan dalam penelitian ini kurang banyak karena insidensi infeksi dengue pada bulan Oktober-Desember 2017 masih sedikit. Pada penelitian ini diketahui persebaran jenis kelamin dari sampel yang diteliti, didapatkan $66,7 \%$ sampel berjenis kelamin perempuan dan $33,3 \%$ sampel berjenis kelamin laki-laki. Hasil ini sesuai dengan penelitian yang bahwa perempuan memiliki peluang 3,333 kali lebih tinggi menderita DBD daripada laki-laki. ${ }^{12}$

Pada penelitian ini, semua anak dengan diagnosis infeksi dengue memiliki jumlah trombosit yang rendah atau trombositopenia $\left(<150.000 / \mathrm{mm}^{3}\right)$. Hal ini sesuai dengan perjalan penyakit infeksi dengue, dimana pada hari-hari pertama demam, jumlah trombosit pasien infeksi dengue masih cenderung normal, kemudian dapat menurun secara drastis atau mencapai titik terendah pada fase kritis. Mungkin saja pada penilitian ini, karakteristik pasien anak yang mengalami infeksi dengue berada pada fase kritis yaitu demam sekitar hari ketiga sampai kelima sehingga ditemukan jumlah penurunan jumlah trombosit atau trombositopenia. ${ }^{5}$

Hubungan jumlah trombosit terhadap manifestasi perdarahan dianalisis menggunakan uji fishers's exact yang disajikan dalam tabel 18, diperoleh hasil $p$ value sebesar 0,015 . Nilai $p$ value yang didapatkan lebih kecil dibandingkan nilai $\alpha$ atau batas kemaknaan $(\alpha=0,05)$. Dapat dikatakan bahwa terdapat hubungan bermakna antara jumlah p-value yang didapat berdasarkan uji statistik adalah 1,00 .

Berdasarkan analisis bivariat antara kadar hemoglobin dengan manifestasi perdarahan yang disajikan dalam tabel 11, diketahui bahwa pasien dengan kadar hemoglobin rendah atau kurang dari $10 \mathrm{~g} / \mathrm{dl}$, yang mengalami perdarahan sedang sebanyak 1 pasien dan tidak didapatkan pasien yang mengalami perdarahan ringan. Sedangkan pasien dengan kadar hemoglobin normal atau 10-16 g/dl, yang mengalami perdarahan ringan sebanyak 9 pasien dan 14 pasien mengalami perdarahan sedang. Berdasarkan uji statistik, $p$ value yang didapatkan yaitu 1,00 .

trombosit terhadap manifestasi perdarahan pada pasien anak dengan diagnosis infeksi dengue.Pada penilitan ini didapatkan bahwa jumlah trombosit kurang dari $100.000 / \mathrm{mm}^{3}$ lebih banyak mengakibatkan manifestasi perdarahan sedang.

Pada infeksi dengue, manifestasi klinis yang umum terjadi adalah manifestasi perdarahan. Manifestasi ini dapat dipengaruhi oleh penurunan jumlah trombosit. Trombositopenia terjadi karena supresi sumsum tulang oleh virus dengue sehingga produksi trombosit menurun dan virus dengue juga dapat menginfeksi megakariosit sehingga meningkatkan destruksi trombosit. Selama infeksi dilepaskan sitokin diantaranya macrophage inflammatory protein-1 $\alpha$ (MIP1a), IL6 dan IL-8. Berbagai sitokin tersebut dapat menghambat pertumbuhan sel progenitor hemopotetik awal. Terjadi juga penurunan Stem Cell Factor (SCF) yang menyebabkan penurunan sel progenitor hemopoetik. Sitokin yang mensupresi haemopoesis dilepaskan ke dalam aliran darah pada fase awal demam dengue, yaitu tumor necroting factor (TNF- $\alpha$ ), interleukins (IL-2, IL-6, IL-8) dan interferon (INF- $\alpha$ dan INF- $\gamma$ ). Parahnya kondisi klinis pasien infeksi virus dengue dan periode terjadinya supresi sumsum tulang tergantung dari kadar sitokin tersebut. Selain itu, dapat juga terjadi pengaktifan faktor Hageman (XIIa) oleh komplekvirus-antibodi yang akan mengganggu sistem koagulasi dan fibrinolysis sehingga memperberat perdarahan serta mengaktifkan sistem kinin dan komplemen yang mengakibatkan peningkatan 
permeabilitas pembuluh darah dan kebocoran plasma serta meningkatkan risiko terjadinya KID yang juga memperberat perdarahan. ${ }^{1}$

Hasil penelitian ini sesuai bahwa terdapat hubungan yang bermakna antara penurunan jumlah trombosit dengan risiko terjadinya terjadinya perdarahan berat pada pasien DBD dengan uji fisher's exact dengan nilai $p$-value sebesar 0,044 . Penelitian lainnya juga menunjukkan hubungan yang bermakna antara jumlah trombosit dengan manifestasi perdarahan, dimana nilai $p$-value yang diperoleh sebesar 0,000. Pada penelitian ini juga dikatakan bahwa pada infeksi dengue, tidak hanya selalu diikuti dengan manifestasi perdarahan, tapi dapat juga diikuti dengan perubahan hasil pemeriksaan darah tepi, koagulasi dan fibrinolisis namun perubahan tersebut mungkin sulit dideteksi secara signifikan pada infeksi dengue tanpa komplikasi. $^{1,8}$

Penelitian lainnya menyatakan bahwa pemeriksaan laboratorium dasar seperti jumlah trombosit dapat dijadikan sebagai prediktor perdarahan pada pasien anak dengan infeksi dengue. Pada penelitian ini diketahui bahwa jumlah trombosit kurang dari $51.000 / \mathrm{mm}^{3}$ memiliki risiko 3,4 kali lebih tinggi terjadi perdarahan mukosa. Pada penelitian ini didapatkan hasil bahwa tidak terdapat hubungan antara jumlah trombosit dengan manifestasi perdarahan. Hal ini dapat disebabkan karena faktor yang menyebabkan perdarahan bukan hanya melibatkan faktor trombosit, tapi dapat juga dipengaruhi oleh peningkatan permeabilitas vaskular, gangguan faktor koagulasi dan fibrynolisis degradation product. ${ }^{13,14}$

Pada pemeriksaan jumlah leukosit, didapatkan pasien dengan leukopenia sebesar $54,2 \%$ dan pasien dengan jumlah leukosit normal sebesar $45,8 \%$. Hal ini menunjukkan jumlah yang tidak jauh berbeda antara jumlah pasien yang mengalami leukopenia dengan jumlah pasien yang memiliki jumlah leukosit normal. Pada analisis bivariat jumlah leukosit terhadap manifestasi perdarahan, didapatkan $p$ value 0,423 . Nilai $p$ value yang didapatkan lebih besar dibandingkan nilai $\alpha$ atau batas kemaknaan $(\alpha=0,05)$. Dapat disimpulkan bahwa tidak terdapat hubungan bermakna antara jumlah leukosit dengan manifestasi perdarahan.
Pada fase perjalaan penyakit dengue, jumlah leukosit mulai menurun atau leukopenia dapat terjadi pada hari pertama hingga hari ketiga demam dan mencapai puncaknya sesaat sebelum demam turun dan normal kembali pada 2-3 hari setelah defervescence. Leukopenia sebagian besar disebabkan oleh supresi sumsum tulang, hal ini akan mengakibatkan adanya degenerasi sel PMN yang matur dan pembentukan sel PMN muda. Mekanisme hubungan leukosit dengan manifestasi perdarahan belum diketahui secara pasti, namun penurunan jumlah leukosit ini umumnya diikuti dengan penurunan jumlah trombosit, dimana penurunan jumlah trombosit (trombositopenia) merupakan salah satu penyebab dari manifestasi perdarahan. Penurunan jumlah leukosit dan trombosit ini mencapai puncaknya bersamaan dengan turunnya demam. ${ }^{5}$

Pada penelitian ini tidak didapatkan hubungan yang bermakna antara jumlah leukosit dengan manifestasi perdarahan. Mungkin saja hal ini disebabkan karena perbedaan karakteristik pasien anak pada penelitian ini, dimana jumlah pasien yang mengalami leukopenia hampir sama dengan jumlah pasien yang memiliki jumlah leukosit normal. Hasil ini sesuai dengan yang menyatakan bahwa tidak terdapat hubungan yang bermakna antara jumlah leukosit terhadap manifestasi perdarahan, dengan analisis uji chi square didapatkan $p$-value sebesar $0,186 .{ }^{13}$

Pada pemeriksaan nilai hematokrit, didapatkan pasien dengan nilai hematokrit meningkat sebanyak $41 \%$ dan pasien yang memiliki nilai hematokrit rendah sebesar $59 \%$. Hal ini menunjukkan bahwa tidak terdapat perbedaan yang signifikan antara jumlah pasien yang memiliki nilai hematokrit normal dan pasien yang memiliki nilai hematokrit meingkat. Berdasarkan analisis bivariat antara jumlah leukosit dengan manifestasi perdarahan didapatkan nilai $p$-value sebesar 1,00 . Nilai $p$ value yang didapatkan lebih besar dibandingkan nilai $\alpha$ atau batas kemaknaan $(\alpha=$ 0,05). Dapat dikatakan bahwa tidak terdapat hubungan bermakna antara nilai hematokrit dengan manifestasi perdarahan. Hal ini mungkin saja disebabkan karena perbedaan karakteristik pasien pada penelitian ini, dimana tidak terdapat jumlah yang jauh berbeda antara jumlah pasien dengan nilai hematokrit meningkat yang mengalami perdarahan dan 
jumlah pasien dengan hematokrit normal yang mengalami perdarahan.

Pada infeksi virus dengue, manifestasi perdarahan dapat juga disebabkan karena vaskulopati. Vaskulopati merupakan karakteristik infeksi dengue yang menjadi indikator terbaik dalam keparahan kebocoran plasma. Kebocoran plasma dapat bermanifestasi sebagai hemokonsentrasi sehingga kadar hematokrit meningkat. Kebocoran plasma berlangsung sangat cepat namun dapat diatasi dalam 1 sampai 2 hari pada pasien yang mendapat resusitasi cairan yang tepat. Kebocoran plasma diakibatkan karena kerusakan endotel yang terinfeksi virus dengue. Sel endotel yang terinfeksi dapat menyebabkan pelepasan sitokin dan kemokin IL-6, IL-8 dan RANTES. Selain itu juga dapat mengaktifkan komplemen dan menginduksi ekspresi molekul adhesi seperti ICAM-1. Ekspresi ICAM-1 bersamaan dengan produksIL-8 dan RANTES akan mengundang sel polimorfonuklear, sel mononuklear dan akhirnya melepaskan penanda kerusakan endotel yaitu trombomodulin. Sel endotel berperan penting dalam menjaga hemostasis, oleh karena itu, kerusakan endotel dapat mempengaruhi keseimbangan endothelium prokoagulan atau antikoagulan yang meningkatkan risiko perdarahan. Manifestasi perdarahan yang biasanya timbul karena vaskulopati yaitu tes tourniquet positif atau ptekie. $^{15,16}$

Hasil penelitian ini sesuai dengan penelitian yang dilakukan oleh Livina et al (2012) yang menyatakan bahwa tidak terdapat hubungan bermakna antara nilai hematokrit terhadap manifestasi perdarahan dengan nilai $p$-value sebesar 0,153 menggunakan analisis koefisien korelasi spearman. Namun dalam penelitian ini didapatkan hasil bahwa terdapat hubungan antara jumlah trombosit dengan nilai hematokrit. Nilai p-value sebesar 0,000 menggunakan analisis korelasi Spearman dan

\section{KESIMPULAN DAN SARAN}

Pada penelitian ini dapat disimpulkan bahwa terdapat hubungan yang bermakna antara jumlah trombosit terhadap manifestasi perdarahan, namun tidak terdapat hubungan didapatkan nilai $\mathrm{r}$ sebesar $-0,183$ yang berarti memiliki korelasi negatif lemah. Hal ini menunjukkan bahwa semakin tinggi nilai hematokrit maka akan semakin rendah jumlah trombositnya. Hasil ini sesuai dengan fase perjalanan penyakit dengue, dimana saat fase kritis nilai hematokrit mencapai puncaknya dan jumlah trombosit mencapai titik terendah. ${ }^{5,17}$

Pada pemeriksaan kadar hemoglobin, didapatkan pasien dengan kadar hemoglobin rendah sebanyak $4 \%$ dan pasien dengan kadar hemoglobin normal sebanyak $96 \%$. Terdapat jumlah yang jauh berbeda antara jumlah pasien dengan kadar hemoglobin normal dan jumlah pasien dengan kadar hemoglobin rendah. Hal ini mungkin disebabkan karena hampir $80 \%$ pasien pada penelitian ini mengalami DBD dan hanya $20 \%$ pasien yang mengalami DD. Pada DD penurunan hemoglobin ini dapat terjadi karena supresi sumsum tulang oleh virus dengue, sedangkan pada DBD sudah terjadi kebocoran plasma sehingga hematokrit meningkat dan kadar hemoglobinpun ikut meningkat mengkuti kenaikan hematokrit.

Berdasarkan uji statistik, $p$-value yang didapatkan yaitu 1,00. Nilai p-value yang didapat berdasarkan uji statistik adalah 1,00. Nilai $p$ valueyang didapatkan lebih besar dibandingkan nilai $\alpha$ atau batas kemaknaan $(\alpha=$ $0,05)$. Hal ini berarti tidak terdapat hubungan bermakna antara kadar hemoglobin dengan manifestasi perdarahan. Kadar hemoglobin juga dapat menurun saat terjadi perdarahan berat seperti perdarahan saluran cerna.Namun pada penelitian ini, tidak didapatkan sampel yang mengalami perdarahan berat seperti hematemesis atau melena. Hasil penelitian ini serupa dengan penelitian yang menunjukkan bahwa lebih dari $50 \%$ pasien infeksi dengue memiliki kadar hemoglobin normal. Pada penilitian yang telah dilakukan penulis juga didapatkan pasien dengan kadar hemoglobin normal diatas $50 \%{ }^{18}$

bermakna antara jumlah leukosit, nilai hematokrit dan kadar hemoglobin terhadap manifestasi perdarahan pada pasien anak infeksi dengue. 


\section{DAFTAR PUSTAKA}

1. Bashir, Mohammed, Saeed, Ageep. 2015. Thrombocytopenia and bleeding manifestations among patients with dengue virus infection in Port Sudan, Red Sea State of Sudan. Academic Journals, 7(2):7-13.

2. Dinas Kesehatan Kota Bandar Lampung. 2013. Profil Kesehatan Kota Bandar Lampung Tahun 2014. Bandar Lampung: Dinkes Kota Bandar Lampung.

3. Ikatan Dokter Anak Indonesia. 2012. Buku Ajar Infeksi \& Pediatri Tropis. Jakarta: Badan Penerbit IDAI.

4. Ginanjar. (2008). Demam berdarah. Yogyakarta: PT. Bentang Pustaka.

5. World Health Organization. 2009. Dengue: guidelines for diagnosis, treatment, prevention, and control. France: WHO.

6. Souza LJD, Souza LAD, Pessanha BL, Mansur LC, Filho JTDS, Silveira MDV, et al. 2013. Comparison of clinical and laboratory characteristics between children and adults with dengue. Brazilian $J$ Infect Dis, 17(1):27-31.

7. Jain H. 2016. Clinical profile and outcome of dengue fever in hospitalized children of South Rajasthan, India. Int J Contemp Pediat,. 3(2):546-9.

8. Yuwono IF. 2007. Penurunan Jumlah Trombosit sebagai faktor risiko terjadinya perdarahan pada pasien demam berdarah dengue dewasa di rsup dr. kariadi semarang. [Skripsi]. Semarang: Universitas Diponegoro.

9. Narayanan M, Aravind MA, Ambikapathy P, Prema R, Jeyapaul MP. 2003. Dengue fever - clinical and laboratory parameters associated with complications. Dengue Bulletin, 27:108-15.

10. Mittal H, Faridi MMA, Arora SK. 2012. Clinicohematological profile and platelet trends in children with dengue during 2010 epidemic in north india. Indian $J$ Pdiatr, 79:467-71.

11. Risniati Y, Tarigan LH, Tjitra E. 2011. Leukopenia sebagai prediktor terjadinya sindrom syok dengue pada anak dengan demam berdarah dengue di rspi. prof. dr. sulianti saroso. Media Litbang Kesehatan, 21:96-103.

12. Novitasari A, Ramaningrum G, P DY. 2013. Analisis faktor yang mempengaruhi derajat Infeksi dengue pada anak. Jurnal Kedokteran Universitas Muhammadiyah Semarang, 4:17.

13. Huwae IR, Kadafi KT. 2003. Peripheral blood examination to assess bleeding risk in children with dengue infections. Paediatr Indones, 49(6):158-61.

14. Fitriastri NH, Nilapsari R, Kusmiati M. 2015. Hubungan trombositopenia dengan manifestasi klinis perdarahan pada pasien demam berdarah dengue anak. Prosiding Pendidikan Dokter, 10-6.

15. Lei HY, Huang, K.J, Lin YS, Yeh TM, Liu HS, Liu CC. 2008. Immunopathogenesis of dengue hemorrhagic fever. Am. J. Infect. Dis, 4(1), 1-9.

16. Tjahjono G, Widiyanti $\mathrm{P}$, Nasronudin. 2016. Clinical Manifestation Approach of Dengue Viral. Indones $J$ Trop Infect diease, 6(2):39-45.

17. Livina A, Rotty LWA, Panda AL. 2014. Hubungan trombositopenia dan hematrokit dengan manifestasi perdarahan pada penderita demam dengue dan demam berdarah dengue. ECL, 2(1):1-8.

18. Mehboob R, Munir M, Azeem A, Naeem S, Ahmad F. 2015. Low platelet count associated with dengue hemorrhagic fever. Int J Adv Chem, 1(1):31-6. 